\title{
Sex differences in the rapid and acute effects of estrogen on striatal $D_{2}$ dopamine receptor binding
}

\author{
Terence J. Bazzett ${ }^{\text {a,b }}$, Jill B. Becker a,c,* \\ ${ }^{a}$ Psychology Department, Reproductive Sctences Program, ${ }^{b}$ Neurology Department, ${ }^{c}$ Neuroscience Program, Unversity of Michigan, \\ Neuroscience Laboratory Bulding, 1103 East Huron St., Ann Arbor, MI 48104-1687, USA
}

(Accepted 5 October 1993)

\begin{abstract}
Regional changes in striatal $\mathrm{D}_{2}$ dopamine (DA) receptor binding in castrated (CAST) or ovariectomized (OVX) rats were investigated following administration of a low dose of estradiol benzoate (EB), repeated treatment with EB followed by progesterone, or vehicle. In two separate experıments, there was a significant decrease in striatal $D_{2}$ DA receptor binding in caudal striatum from OVX, but not CAST rats $30 \mathrm{~min}$ after a single injection of EB. In CAST rats, there was a significant increase in striatal $\mathrm{D}_{2}$ DA receptor binding in rostral striatum $4 \mathrm{~h}$ after injection of EB. There was no effect of EB plus progesterone treatment in either OVX or CAST rats. In addition, CAST rats had significantly lower $\mathrm{D}_{2}$ DA receptor binding in the lateral region of the rostral striatum than did OVX rats. These results show sexually dimorphic and regionally specific effects of estrogen on striatal $D_{2}$ DA receptor binding, and a significant sex difference in striatal $D_{2}$ DA receptor binding in the absence of circulating gonadal hormones. The present findings are discussed in light of previous reports of sex differences in gonadal hormone influences on striatal DA mediated behaviors.
\end{abstract}

Key words: Estradiol; Dopamine receptor; Sex differences; Striatum; Quantitative autoradiography; Progesterone

\section{Introduction}

Gonadal steroid hormones have been shown to affect $\mathrm{D}_{2}$ dopamine (DA) receptor binding in rat striatum $[4,5,7,9,10,11,14,16,18,20,23,27,28,35]$. Of the gonadal steroid hormones, estrogen has received the most attention in this regard. Although there have been apparent discrepancies in the results, an analysis of the differences among the protocols across research groups reveals some consistent effects of estrogen on striatal $\mathrm{D}_{2}$ DA receptor binding.

The effect of estrogen on striatal $\mathrm{D}_{2}$ DA receptor binding varies with the dose of estrogen, the sex of the animal, the duration of estrogen treatment, and the period of time after estrogen treatment when receptor binding was measured. For example, two laboratories have reported increased striatal $D_{2}$ DA receptor binding following repeated administration of high doses of

\footnotetext{
* Corresponding author Fax (1) (313) 936-2690. Emall: userGDFL@umichum.bitnet
}

estrogen. Di Paolo et al. [6,7,9] found that $20 \mu \mathrm{g} /$ day $17 \beta$-estradiol for 14 days increased the $B_{\text {max }}$ for striatal $\mathrm{D}_{2}$ DA receptors in ovariectomized (OVX) female rats $24 \mathrm{~h}$ after the last estradiol injection. Other methods used to chronically elevate circulating estrogen levels have produced similar results. For example, in intact female rats there was a significant increase in the $B_{\max }$ for striatal $D_{2}$ DA receptors after one month exposure to subcutaneous pellets containing $10 \mathrm{mg}$ estradiol benzoate (EB) [14]. Chronic elevation of circulating estrogen following a single injection of the long acting estradiol valerate also increased the $B_{\max }$ for striatal $\mathrm{D}_{2}$ DA receptors in both intact male and OVX rats $[18,20,23]$.

Taken together, the studies discussed above suggest that chronic elevation of circulating estrogen increases striatal $\mathrm{D}_{2}$ DA receptor binding. In each of the above experiments, however, the dose of estrogen used to produce effects was considerably higher than that required to approximate circulating estrogen concentrations in an intact female rat. Thus, there are inherent difficulties in relating findings from studies using 
chronic high doses of estrogen, to results of studies that examine changes in striatal $D_{2}$ DA receptor binding that occur in response to brief changes in physiological concentrations of circulating estrogen, such as those that occur during the four day estrous cycle.

Work by Gordon and colleagues $[5,16]$ has shown that the effect of estrogen on striatal DA receptor binding can vary with the time after hormone treatment. These investigators treated OVX rats with $25 \mu \mathrm{g}$ $\mathrm{EB} /$ day for 3 days and found that there was decreased affinity for DA receptor binding $24 \mathrm{~h}$ after the last injection $[4,16]$. By contrast, $48-96 \mathrm{~h}$ after the final EB injection the $B_{\max }$ for striatal $D_{2}$ DA receptors was increased $[5,16]$. Thus, even with a relatively high dose of estrogen, when the duration of the treatment period more closely approximates the period of the estrous cycle the effect of estrogen is different from that seen with more chronic treatment.

Studies that have investigated changes in striatal $D_{2}$ DA receptor binding in response to low doses of estrogen or estrous cycle dependent changes in circulating estrogen have also consistently found effects that are quite different from the response to chronic high dose treatment. For example, the ratio of high/low affinity states of striatal $\mathrm{D}_{2}$ DA receptors is greater during diestrus, when circulating estrogen is low than during proestrus when circulating estrogen levels are rapidly rising [8]. Using a dose of EB that approximates the endogenous serum concentrations of estrogen, Tonnaer and colleagues [35] found that $2.5 \mu \mathrm{g} \mathrm{EB} /$ day for 7 days decreased the affinity of striatal $D_{2}$ DA receptors $24 \mathrm{~h}$ after the final $\mathrm{EB}$ injection in OVX rats. Similarly, Levesque and DiPaolo [27] found that administration of a single low dose $(100 \mathrm{ng})$ of $17 \beta$ estradiol to OVX rats also resulted in conversion of high affinity $D_{2}$ DA binding sites to low affinity binding sites $30 \mathrm{~min}$ after injection. Reducing circulating estrogen by ovariectomy, on the other hand, significantly increased the ratio of high/low affinity state of striatal $\mathrm{D}_{2}$ DA receptors [27]. To date, an effect of an acute physiological dose of estrogen on striatal $\mathrm{D}_{2} \mathrm{DA}$ receptor binding in male rats has not been reported.

The studies discussed above have all used homogenates of striatal tissue to determine whether estrogen affects striatal $D_{2}$ DA receptor binding. However, the striatum is structurally and functionally heterogeneous. As described by Gerfen ([13], p. 19), "the dorsal region of the striatum receives inputs from sensorimotor cortical areas (among other areas) and projects to the substantia nigra pars reticulata, whereas the ventral striatum receives inputs from limbic brain areas such as the olfactory cortex, amygdala and hippocampus and projects to the substantia nigra pars compacta". In addition, there is compartmentation within the striatum, referred to as the patch/matrix organization [13]. Superimposed on this already com- plex organization of the striatum, there is a lateral to medial gradient in the binding density of $D_{2}$ DA receptors [25]. In the only studies reporting regional effects of systemıcally administered estradıol on strıatal DA receptors, $20 \mu \mathrm{g} /$ day EB for 14 days increased the number of striatal $D_{2}$ DA receptors selectively in the lateral portion of the striatum in OVX rats $24 \mathrm{~h}$ after the last EB injection $[12,26]$. Thus, the effects of estrogen on striatal $D_{2}$ DA receptor binding may be regionally specific.

The present studıes were designed to further delineate the regional specificity of striatal $D_{2}$ DA receptor binding changes that respond to physiological concentrations of gonadal steroid hormones. Regional effects were examined following administration of an acute low dose of estrogen to gonadectomized male and female rats. In addition, the effect of a hormone administration regimen designed to approximate the rat's estrous cycle was examined in both male and female gonadectomized rats.

\section{Materials and Methods}

\section{Subjects}

Adult male and female Holtzman rats (Harlan Sprague-Dawley Inc, Indianapolıs, IN) were gonadectomized under ether anesthesia in accordance with guidelines set by the University Committee on Use and Care of Anımals All anımals were allowed 14 days to recover from surgery. Durıng that time cells from the vaginal epithelium of OVX rats were examined dally for 10 days, only OVX rats with vaginal epithelial cells showing no evidence of cornified cells were used for the remainder of the experiment

\section{General procedures}

Horizontal brain sections from a total of 18 castrated (CAST) male and 22 OVX rats were analyzed for the first experıment. Rats were assigned to one of three treatment groups. Estradiol benzoate (EB) and progesterone (Sigma Chemical Co, St Louis, MO) were dissolved in peanut oll and injected subcutaneously. One group of 6 CAST and 7 OVX rats recelved $20 \mu \mathrm{g} \mathrm{EB} / \mathrm{kg}$ for three days and 4.8 $\mathrm{mg}$ progesterone $/ \mathrm{kg}$ on the fourth day. These doses of $\mathrm{EB}$ and progesterone produce serum concentrations within the physiological range [2,17]. Anımals from this group were killed by decapitation $4 \mathrm{~h}$ after the progesterone injection $(E B+P)$. A second group of 6 CAST and $8 \mathrm{OVX}$ rats received three days of vehicle (peanut oil) injections and a single injection of $20 \mu \mathrm{g} \mathrm{EB} / \mathrm{kg}$ on the fourth day Animals from this group were killed by decapitation $30 \mathrm{~mm}$ after the EB mjection (EB.30) A third group of 6 CAST and 7 OVX rats received four days of vehicle injections. Half of the anımals from this group were killed by decapitation $30 \mathrm{~min}$ after the final injection, the other half $4 \mathrm{~h}$ after injection (OIL)

Coronal brain sections from a total of $23 \mathrm{CAST}$ and $20 \mathrm{OVX}$ rats were analyzed for the second experıment in order to determine if a single injection of $E B$ would produce changes in striatal $D_{2} D A$ receptor binding $30 \mathrm{~min}$ or $4 \mathrm{~h}$ after injection. Rats of each sex were assigned to one of three treatment groups. In the first group, 5 CAST and 6 OVX rats each received $20 \mu \mathrm{g} \mathrm{EB} / \mathrm{kg}$ and were klled by decapitation $30 \mathrm{~min}$ after the injection $(\mathrm{EB} \cdot 30)$. In the second 

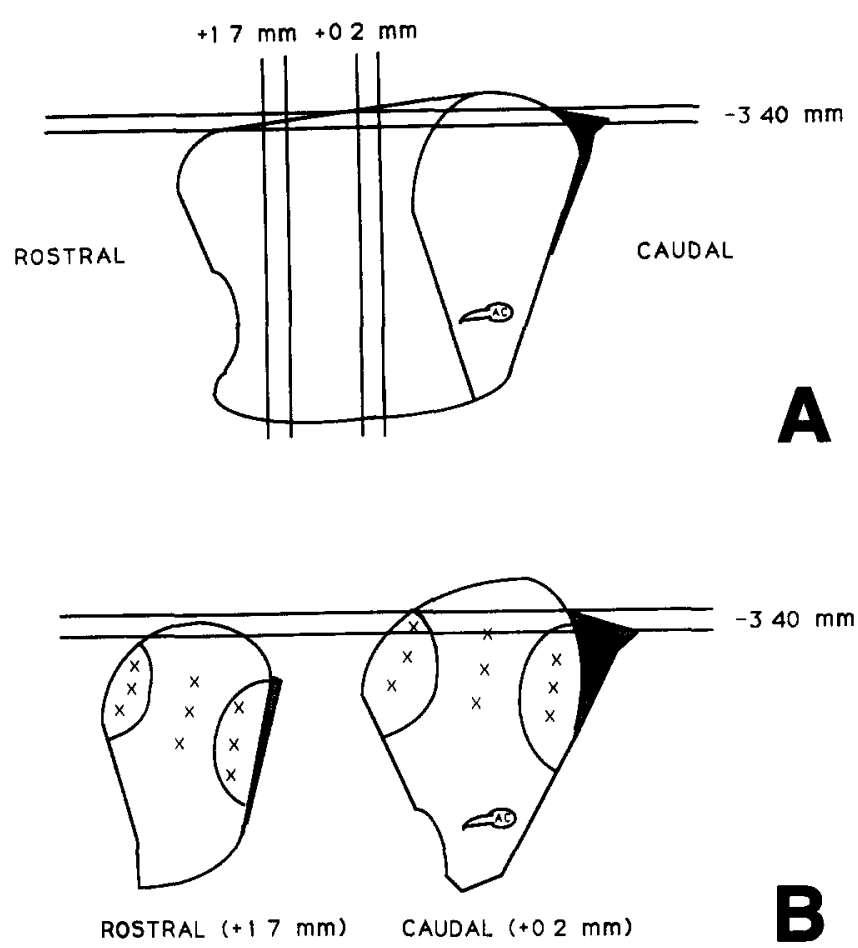

Fig. 1. A schematic diagram illustratıng the relative positıons of the horizontal and coronal sections taken for this study. A: the left striatum is depicted with lines through the horizontal and coronal planes that were sectioned Values indicated the approximate distance from bregma (skull flat) estımated from Paxinos and Watson [29]. The darkened area at the top right of the striatum is the lateral ventricle. B: schematic drawings of the shapes of the left striatum at the two coronal planes, with the plane of the horizontal sections indicated with the horizontal lines Note that horizontal sections were sampling primarily caudal striatum $\mathrm{AC}$, anterior commısure; $\mathrm{LV}$, lateral ventricle.

treatment group, $7 \mathrm{CAST}$ and $6 \mathrm{OVX}$ rats each recerved $20 \mu \mathrm{g}$ $\mathrm{EB} / \mathrm{kg}$ and were kılled by decapitation $4 \mathrm{~h}$ after injection (EB:4). In the third treatment group, 11 CAST and 8 OVX rats each received a vehicle injectıon Half of the anımals from the vehicle group were killed by decapitation $30 \mathrm{~min}$ after the final injection, the other half 4 $\mathrm{h}$ after injection (OIL). Coronal sections were used to allow assessment of both rostral and caudal regions of the striatum, since only caudal regions of the striatum were represented in the horizontal sections obtained in the first experiment (Fig. 1).

For all anımals, brains were rapidly removed following decapitation and immediately frozen on dry-ıce Brains were then stored at $-70^{\circ} \mathrm{C}$ until being sectioned on a cryostat for autoradıgraphic assay

\section{Quantttattve dopamine receptor autoradıgraphy}

Quantitative receptor autoradiography for striatal $D_{2}$ DA receptor binding as indicated by $\left[{ }^{3} \mathrm{H}\right]$ spiperone binding was conducted using methods described in detall elsewhere [32] In brief, for horızontal sections, five consecutive $20 \mu \mathrm{m}$ frozen sections were collected using a cryostat at $-18^{\circ} \mathrm{C}$ Sections were cut on a horizontal plane between approxumately -3.4 and $-3.6 \mathrm{~mm}$ from the dorsal surface. For coronal sections, five consecutive $20 \mu \mathrm{m}$ frozen sections were cut on a coronal plane starting approxımately $17 \mathrm{~mm}$ anterior from bregma (rostral striatum), and 5 sections were similarly collected starting approxımately $0.2 \mathrm{~mm}$ anterior from bregma (caudal striatum). Plane of section and coordinates for brain sections collected were determined by comparıng sections with the illustrations In Paxinos and Watson [31] as they were being cut. Sections were thaw-mounted onto gelatın-coated slides, and stored at $-70^{\circ} \mathrm{C}$ until assayed. The $\mathrm{D}_{2}$ DA receptor bunding assay was conducted using a buffer containıng $25 \mathrm{mM}$ Tris- $\mathrm{HCl}$ (pH 75), $100 \mathrm{mM} \mathrm{NaCl}, 1 \mathrm{mM}$ $\mathrm{MgCl}_{2}, 15 \mu \mathrm{M}$ pargyline and $0.001 \%$ ascorbate To determine total $\mathrm{D}_{2}$ DA receptor bindıng, brain sections ( $n=3$ /anmal) were incubated in $\left[{ }^{3} \mathrm{H}\right]$ spiperone (Amersham) at a concentration equal to $K_{d}$ $(250 \mathrm{pM})$ for $25 \mathrm{~h}$ at room temperature $100 \mathrm{nM}$ mianserın (Sigma) was added to the buffer to block $\left[{ }^{3} \mathrm{H}\right]$ spiperone binding to the $5-\mathrm{HT}_{2}$ serotonın receptor subtype To determıne nonspecific bındıng, brain sections ( $n=2$ /anımal) were incubated in $\left[{ }^{3} \mathrm{H}\right]$ spıperone as above, with the addition of $10 \mu \mathrm{M}$ dopamine-HCl After incubation with the tritiated ligand, sections were washed for $10 \mathrm{~min}$ in buffer at $4^{\circ} \mathrm{C}$, dipped in distilled water $\left(4^{\circ} \mathrm{C}\right)$, and then dried using a stream of cool air Sections were then apposed to Amersham Hyperfilm- ${ }^{3} \mathrm{H}$, with previously calibrated $\left[{ }^{14} \mathrm{C}\right]$ methacrylate standards [30] Horizontal sections were apposed to film for 21 days Coronal sections were apposed to film for 16 days Fllms were developed in Kodak D-19 developer and fixed in Kodak rapıd fixer

All binding data were determined directly from film densities Films were analyzed using computer-assisted video densitometry Specific binding for striatal $D_{2}$ DA receptor binding was determıned by subtracting the average densities of non-specific $\left[{ }^{3} \mathrm{H}\right]$ spiperone binding from the average total $\left[{ }^{3} \mathrm{H}\right]$ spiperone binding for each anımal

\section{Regional analysis of the striatum}

In horizontal sections, $\mathrm{D}_{2}$ DA receptor density was quantified in both the lateral and the medial regions of the dorsal striatum ( $F_{1}$. 2A) In coronal sections, $D_{2} D A$ receptor density was quantified in the lateral, central and medial regions of both the rostral and caudal striatum (Fig. 2B)

\subsection{Stattstics}

Data were analyzed by analysis of variance (ANOVA) using Statview $512+$ for the Macintosh computer

\section{Results}

\subsection{Horizontal sections}

Within the OVX and CAST groups, there were no significant differences in $D_{2}$ DA receptor binding between OIL treated animals killed $30 \mathrm{~min}$ after injection and those killed $4 \mathrm{~h}$ after injection. Therefore, data from animals taken $30 \mathrm{~min}$ or $4 \mathrm{~h}$ after oil treatment were combined to yield a single OIL injected group for OVX and a single OIL injected group for CAST rats.

Using these comparison groups, there was a significant decrease in striatal $D_{2}$ DA receptor binding in OVX rats that were killed 30 min after a single EB injection compared to OIL injected OVX rats $\left(F_{1,13}=\right.$ 8.046; $P=0.014$; Fig. 3) and to $E B+P$ injected OVX rats $\left(F_{1,13}=0.0016 ; P=0.0016\right.$; Table I). There was a lateral to medial gradient in $\mathrm{D}_{2} \mathrm{DA}$ receptor binding $(P<0.001)$, and the decrease in $\mathrm{D}_{2} \mathrm{DA}$ receptor binding in these dorsal horizontal sections was found in 


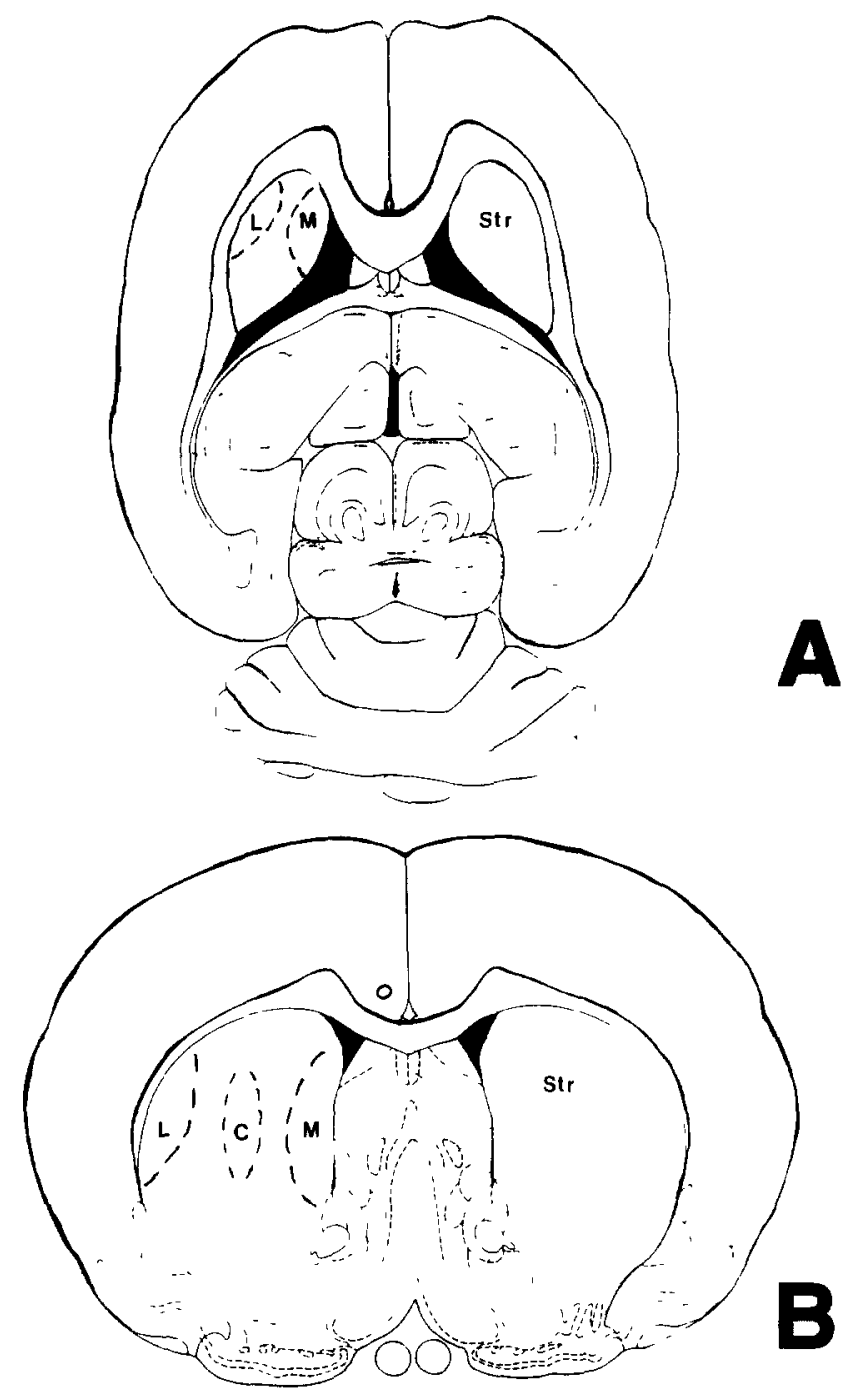

Fig 2. Areas of the striatum sampled for regional analysis of $D_{2} D A$ receptor bindıng density in horizontal (A) and coronal (B) sectıons through the striatum (Str) are depicted. A in horizontal sections, approximately $-36 \mathrm{~mm}$ from top of skull at bregma, lateral $(\mathrm{L})$ and medial (M) areas as indicated above were assessed bilaterally $B \cdot$ in coronal sections, approximately +17 and $+0.2 \mathrm{~mm}$ from bregma (skull flat), as indicated above, the lateral (L), central (C), and medial (M) regions of striatum were assessed bilaterally (Figures adapted from Paxinos and Watson [29].)

both lateral and medial regions of the striatum. Receptor binding in OVX rats that received $\mathrm{EB}+\mathrm{P}$ was not significantly different from OVX rats that received OIL.

In CAST rats, there were no significant differences between the three treatment groups in $\mathrm{D}_{2}$ DA recep- tor binding density. In addition, there were no sex differences in $\mathrm{D}_{2}$ DA receptor binding in horizontal sections (Table 1) which represents the dorsal caudal striatum.

\subsection{Coronal sections}

As was true for the horizontal sections, there were no significant differences within the OVX and CAST groups in $\mathrm{D}_{2} \mathrm{DA}$ receptor binding between OIL treated animals killed $30 \mathrm{~min}$ after injection and those killed 4 $\mathrm{h}$ after injection. Therefore, data from coronal sections of animals taken $30 \mathrm{~min}$ or $4 \mathrm{~h}$ after oil treatment were combined to yield a single OIL injected group for OVX and a single OIL injected group for CAST rats.

Using these comparison groups, there was a significant decrease in $D_{2}$ DA receptor binding in the caudal striatum of OVX rats 30 min after a single injection of EB, compared to OVX rats receiving only vehicle (Fig. 3 ). There was a lateral to medial gradient in the density of $\mathrm{D}_{2}$ DA receptor binding in all groups $(P<0.001)$ and the decrease in $D_{2}$ DA receptor binding was significant in all three regions of the caudal striatum $\left(F_{1,14}=6.33 ; P=0.025\right)$. There was no significant effect of the EB treatment in the rostral striatum of OVX rats, and no effect $30 \mathrm{~min}$ after EB treatment on $\mathrm{D}_{2}$ DA receptor binding in CAST animals (Table II).

By contrast, there was an increase in $\mathrm{D}_{2}$ DA receptor binding in the rostral striatum of CAST rats $4 \mathrm{~h}$ after a single injection of EB, compared to CAST rats receiving only vehicle (Fig. 4). This increase in $D_{2}$ DA receptor binding was significant in all three regions of the rostral striatum $\left(F_{1,16}=15.16 ; P=0.0013\right)$, but was not significant in the caudal striatum (Table II). There was no effect $4 \mathrm{~h}$ after EB treatment on $D_{2}$ DA receptor binding in OVX animals in either region of the striatum.

There was also a sex difference in $\mathrm{D}_{2}$ DA receptor binding in the rostral striatum of OIL injected rats. OIL injected CAST rats had less $\mathrm{D}_{2} \mathrm{DA}$ receptor binding than OIL injected OVX rats (Fig. 5). Both CAST and OVX rats showed the lateral to medial gradient in $\mathrm{D}_{2}$ DA receptor binding $\left(F_{1,2}=58.48 ; P<\right.$ 0.001 ). The sex difference in $D_{2} D A$ receptor binding was significant only in the lateral region of the rostral striatum $\left(F_{1,19}=5.973 ; P=0.0245\right)$, although the trend was evident throughout the lateral to medial gradient (Table II).

Fig. 3. Autoradıograms from OVX rats in representative horızontal (A-D) and coronal $(E-H)$ sections are shown illustrating total $\left[{ }^{3} \mathrm{H}\right]$ spiperone binding (A,B,E,F) and non-specific binding $(\mathrm{C}, \mathrm{D}, \mathrm{G}, \mathrm{H})$ after oll treatment $(\mathrm{A}, \mathrm{C}, \mathrm{E}, \mathrm{G})$ or 30 min after $20 \mu \mathrm{g} \mathrm{EB} / \mathrm{kg}(\mathrm{B}, \mathrm{D}, \mathrm{F}, \mathrm{H})$. There was a significant decrease in specific $D_{2}$ DA receptor binding (total minus blank) 30 min after EB in both horizontal sections $(P=0.014)$ and caudal coronal sections $(P=0025)$ compared with oll treated controls A representative calibration bar for $\mathrm{D}_{2}$ DA receptor bindıng density is shown on the right of the figure. 

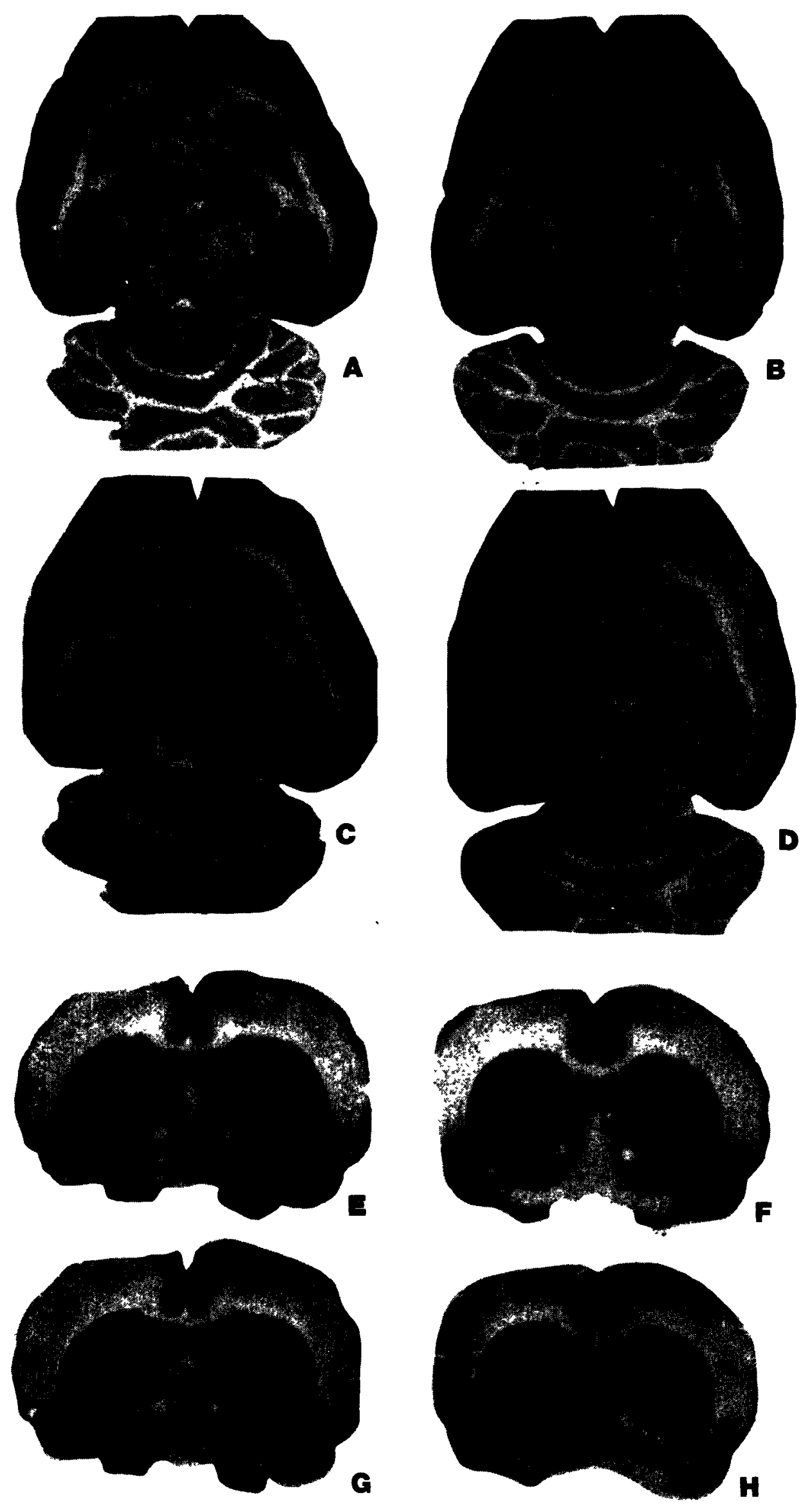
Table 2

$\mathrm{D}_{2}$ DA receptor binding ${ }^{a}$ in coronal sections

\begin{tabular}{|c|c|c|c|c|c|c|c|}
\hline \multirow[t]{2}{*}{ Treatment } & \multirow[t]{2}{*}{ Group $(n)$} & \multicolumn{3}{|l|}{ Rostral } & \multicolumn{3}{|l|}{ Caudal } \\
\hline & & Lateral & Central & Medial & Lateral & Central & Medial \\
\hline OIL & $\begin{array}{l}\text { OVX (10) } \\
\text { CAST (11) }\end{array}$ & $\begin{array}{l}201 \pm 15^{\mathrm{d}} \\
155 \pm 11\end{array}$ & $\begin{array}{l}173 \pm 16 \\
145 \pm 10\end{array}$ & $\begin{array}{l}144 \pm 3 \\
135 \pm 8\end{array}$ & $\begin{array}{l}175 \pm 8 \\
171 \pm 13\end{array}$ & $\begin{array}{l}144 \pm 5 \\
136 \pm 7\end{array}$ & $\begin{array}{l}90 \pm 3 \\
83 \pm 4\end{array}$ \\
\hline EB $\cdot 30$ & $\begin{array}{l}\text { OVX (6) } \\
\text { CAST (5) }\end{array}$ & $\begin{array}{l}168 \pm 31 \\
177 \pm 27\end{array}$ & $\begin{array}{l}154 \pm 26 \\
163 \pm 23\end{array}$ & $\begin{array}{l}139 \pm 19 \\
158 \pm 22\end{array}$ & $\begin{array}{l}135 \pm 19^{b} \\
173 \pm 21\end{array}$ & $\begin{array}{l}111 \pm 13^{h} \\
140 \pm 9\end{array}$ & $\begin{array}{l}72 \pm 9^{1} \\
81 \pm 6\end{array}$ \\
\hline EB 4 & $\begin{array}{l}\text { OVX (6) } \\
\text { CAST (7) }\end{array}$ & $\begin{array}{l}195 \pm 33 \\
236 \pm 22^{c}\end{array}$ & $\begin{array}{l}172 \pm 25 \\
222 \pm 20\end{array}$ & $\begin{array}{l}154 \pm 19 \\
199 \pm 16^{c}\end{array}$ & $\begin{array}{l}168 \pm 21 \\
179 \pm 13\end{array}$ & $\begin{array}{l}133 \pm 17 \\
157 \pm 18\end{array}$ & $\begin{array}{l}77 \pm 7 \\
96 \pm 9\end{array}$ \\
\hline
\end{tabular}

${ }^{\mathrm{a}} \mathrm{pmol} / \mathrm{mg}$ protein; mean $\pm \mathrm{SEM}$.

b $P<0.05$ vs. oll treated rats of the same sex.

${ }^{c} P<005$ vs. oll treated rats of the same sex

d $P<005$ vs male rats from the same treatment group

Since 21 days of film exposure to horizontal sections yielded receptor density counts in the upper third of the standard range, coronal sections were apposed to hyperfilm for 16 days in an effort to avoid a possible ceiling efffect when analyzing films. As anticipated, this reduction in exposure time resulted in lower density readings for coronal sections. $D_{2}$ DA receptor binding $30 \mathrm{~min}$ after EB was decreased $11-15 \%$ in the dorsal caudal horizontal sections and $20-23 \%$ in the caudal coronal sections, suggesting that there may have been a partial ceiling effect with the horizontal sections. Nevertheless, this effect of EB was statistically significant in both experiments.

\section{Discussion}

This is the first report of a sex difference in the effects of EB on striatal $\mathrm{D}_{2} \mathrm{DA}$ receptor binding. Furthermore, there is intrastriatal regional variability in the response to $\mathrm{EB}$ and in the time course of the response. In OVX, but not CAST rats, $\mathrm{D}_{2}$ DA receptor binding in caudal striatum was decreased $30 \mathrm{~min}$ after a single injection of EB. In CAST, but not OVX rats, EB treatment resulted in increased $D_{2}$ DA receptor binding $4 \mathrm{~h}$ later in the rostral striatum. These results demonstrate that the rapid effects of estrogen reported here are both regionally specific and sex-
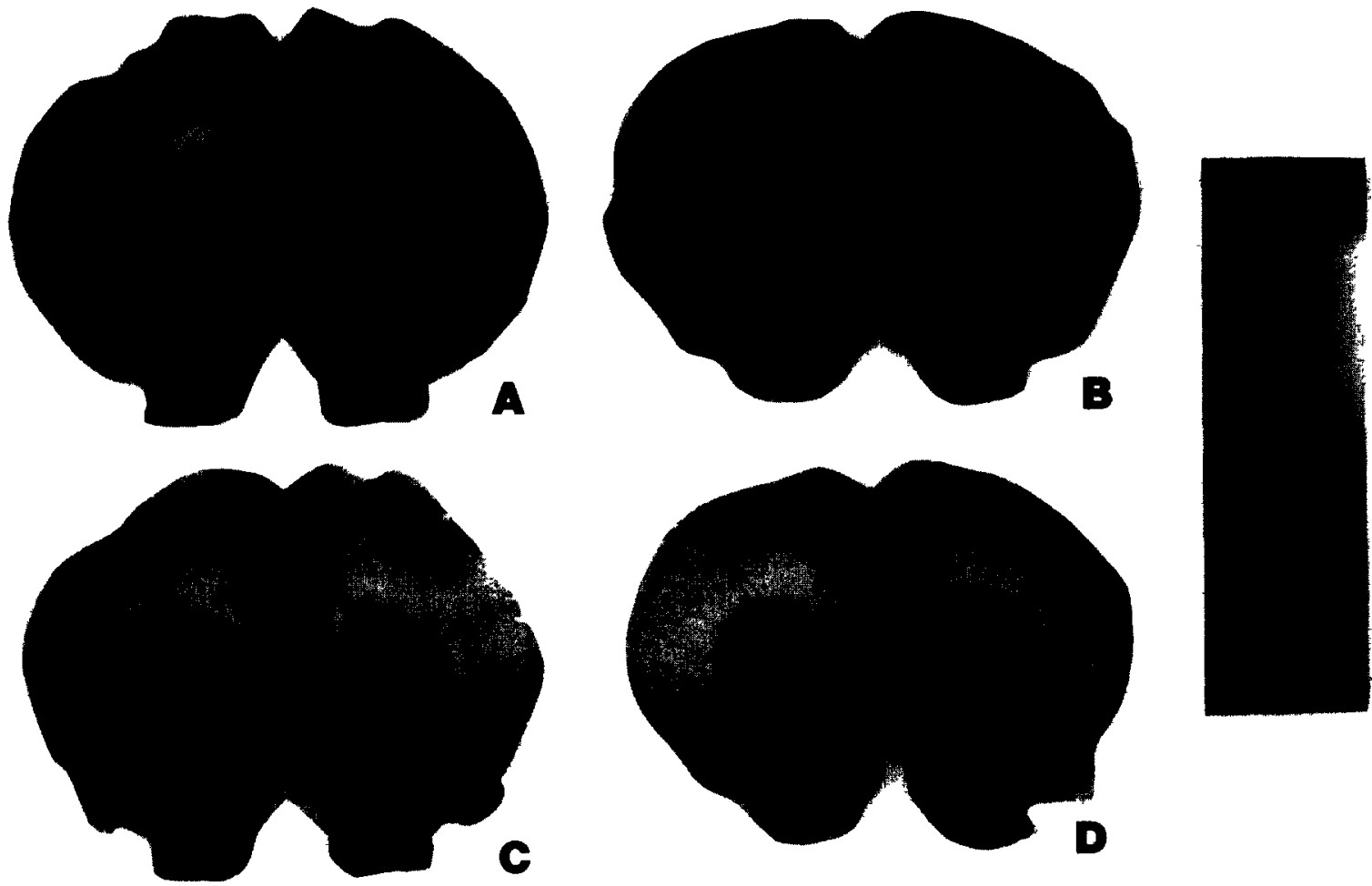

Fig 4. Autoradiograms from CAST rats after oll treatment $(A, C)$ or $4 \mathrm{~h}$ after after $20 \mu \mathrm{g} E B / \mathrm{kg}(\mathrm{B}, \mathrm{D})$ is shown in representative coronal sections illustrating total $\left[{ }^{3} \mathrm{H}\right]$ spiperone binding $(A, B)$ and non-specific bindıng $(C, D)$. Specific $D_{2}$ DA receptor binding (total minus blank) in coronal sections from rostral striatum was significantly increased $4 \mathrm{~h}$ after EB treatment $(P=00013)$ compared with oil treated controls $\mathrm{A}$ calibration bar for $D_{2}$ DA receptor binding density is shown at the right of the figure 

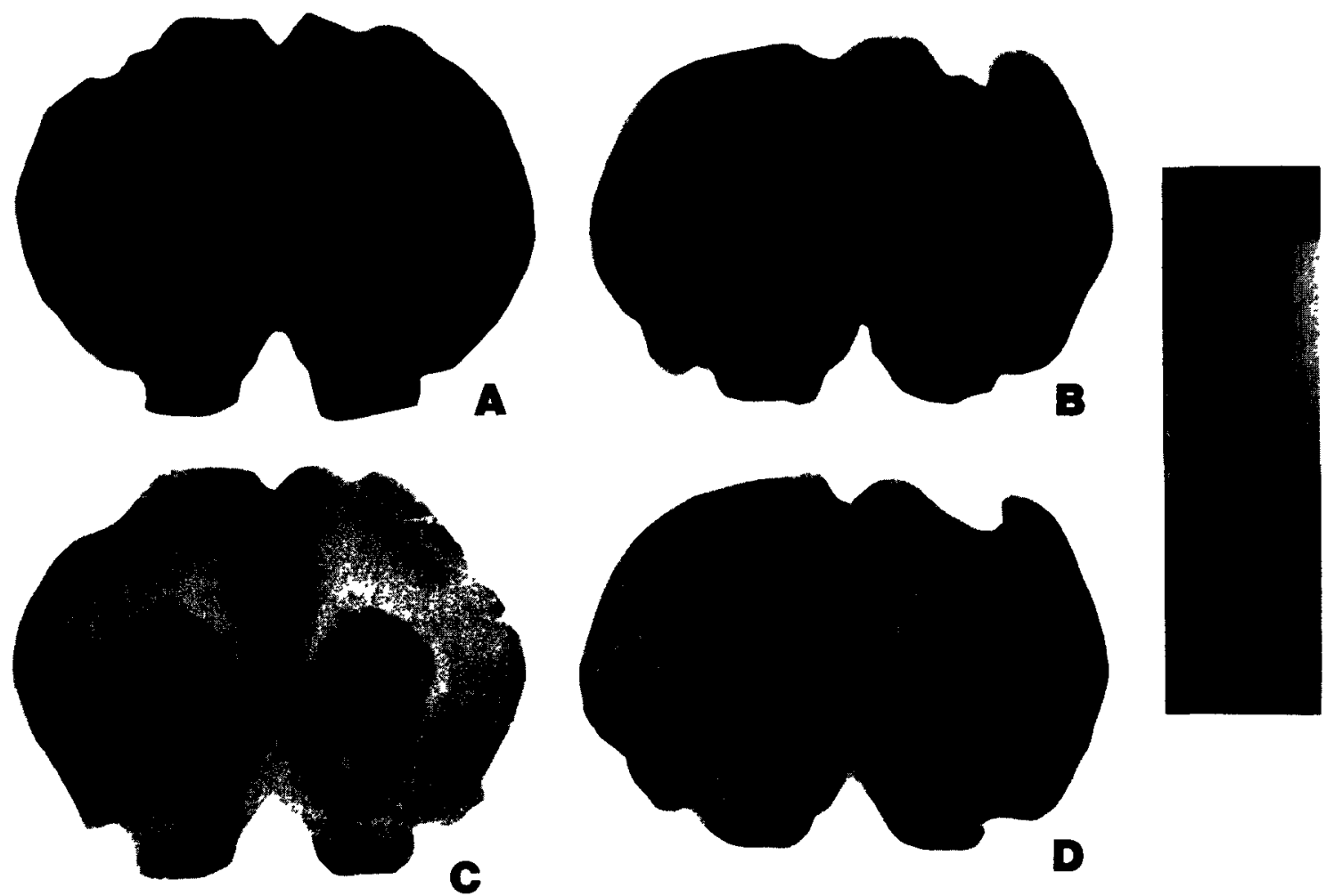

Fig. 5. There were sex differences in specific binding of $\left[{ }^{3} \mathrm{H}\right]$ spiperone in autoradiograms from CAST (A,C) and OVX (B,D) rats. Representative coronal sections from the rostral striatum show total $\left[{ }^{3} \mathrm{H}\right]$ spiperone binding $(A, B)$ and non-specific binding (C,D). In the rostral striatum there was a significant difference in specific $\mathrm{D}_{2}$ DA receptor binding (total minus blank) $(P=0.0245)$ in the absence of gonadal hormones $\mathrm{A}$ calibration bar for $\mathrm{D}_{2}$ DA receptor binding density is shown at the right of the figure.

specific and are not likely to be due to non-specific, generalized effects of estrogen on neuronal membranes. Finally, there was a sex difference in $D_{2} D A$ receptor binding in the lateral region of the rostral striatum where the binding density was lower in CAST than in OVX rats.

Previous research has revealed that neuronal receptors can exhibit rapid changes in response to systemic administration of gonadal hormones. For example, 30 min following progesterone injection, oxytocin receptor binding is 'increased in rat hypothalamus [34]. Rapid

Table 1

$\mathrm{D}_{2}$ DA receptor binding ${ }^{a}$ in horizontal sections

\begin{tabular}{llll}
\hline Treatment & Group $(n)$ & $\begin{array}{l}\text { Medial } \\
\text { striatum }\end{array}$ & $\begin{array}{l}\text { Lateral } \\
\text { striatum }\end{array}$ \\
\hline OIL & OVX (7) & $286 \pm 10$ & $399 \pm 14$ \\
& CAST (6) & $287 \pm 17$ & $386 \pm 27$ \\
EB·30 & OVX (8) & $247 \pm 5^{\text {b }}$ & $358 \pm 16^{\text {b }}$ \\
& CAST (6) & $264 \pm 23$ & $389 \pm 28$ \\
EB+P 4 & OVX (7) & $274 \pm 11$ & $429 \pm 9$ \\
& CAST (6) & $277 \pm 27$ & $386 \pm 28$
\end{tabular}

pmol/mg protein; mean \pm S.E.M

${ }^{\mathrm{b}} P<0.04$ less than OIL or $\mathrm{EB}+\mathrm{P}$ treated females, see text for additional detalls. changes in DA receptor binding have also been reported following estrogen injection. Levesque and $\mathrm{Di}$ Paolo [27] reported a decrease in the ratio of high/low affinity striatal $D_{2}$ DA binding sites in OVX rats 30 min after a single low dose of $17 \beta$-estradiol. The results of Levesque and DiPaolo [27] are in close agreement with the present finding of a rapid decrease in striatal $D_{2} \quad D A$ receptor binding following an acute injection of EB. The present report, however, has extended this finding by showing the response to be sexually dimorphic, occurring in OVX but not CAST rats.

The finding of a lateral to medial gradient in striatal $\mathrm{D}_{2}$ DA receptor binding is in agreement with previous work showing a similar gradient in both $\mathrm{D}_{2}$ DA receptor binding [25] and in $D_{2}$ DA receptor mRNA [26]. Although this lateral to medial distribution of receptors seems well established, few previous studies have assessed regional changes in striatal $D_{2}$ DA receptor binding in response to estrogen treatment. In those studies that have undertaken regional analysis, the effect of estrogen on striatal $D_{2}$ DA receptor binding was reported to be greatest in the lateral region of the striatum. For example, chronic EB treatment was found to increase striatal $D_{2}$ DA receptor binding in lateral, but not the medial striatum $[12,26]$. Crystalline estradiol diluted with cholesterol and introduced directly 
into the striatum also produced an increase in $\mathrm{D}_{2} \mathrm{DA}$ receptor binding in the lateral, but not the medial striatum [33]. Recently Morissette et al. [29] have reported rostral caudal differences in the effects of estradiol on degradation and production rate constants of striatal $\mathrm{D}_{2}$ DA receptors following irreversible blockade. Specifically, estradiol treatment decreased these parameters in the caudal, but not the rostral region of the striatum in OVX rats. In the present report, the decrease in striatal $D_{2}$ DA receptor binding $30 \mathrm{~min}$ after EB was also restricted to the caudal region of the striatum of OVX rats. No effect was found in CAST rats 30 min after EB. Furthermore, this decrease in $D_{2}$ DA receptor binding 30 min after EB was seen in both coronal sections from caudal striatum and in horizontal sections representing dorsal caudal striatum (Fig. 1).

In the present report, the sex difference in $\mathrm{D}_{2} \mathrm{DA}$ receptor binding seen in coronal sections was found to be localized specifically to the lateral rostral striatum, with no sex difference seen in any subregion of the caudal striatum. Since horizontal sections in this report represent primarily the dorsal-caudal region of the striatum (Fig. 1), it is not surprising that a sex difference was not found in sections cut in the horizontal plane.

The report here of a sex difference in the effect of $E B$ on striatal $D_{2}$ DA receptor binding may be related to results from previous reports of the effects of estrogen on stimulated striatal DA release [1,3]. For example, when compared to oil injected controls, amphetamine-stimulated striatal DA release in OVX rats was enhanced $30 \mathrm{~min}$ after estrogen injection using the same dose of $\mathrm{EB}(20 \mu \mathrm{g} / \mathrm{kg})$ as in the present report $[1,3]$. Conversely, CAST rats, do not show an EB-induced enhancement of amphetamine-stimulated striatal DA release [3], and striatal $\mathrm{D}_{2} \mathrm{DA}$ receptor binding is not changed 30 minutes after EB injection (present report). It is possible, therefore, that the rapid decrease in striatal $D_{2}$ DA receptor binding in OVX rats following EB treatment ([27]; present report) is a compensatory response triggered by the EB-induced enhancement of striatal DA release seen in OVX rats $[1,3]$. It should be noted, however, that the effect of EB on amphetamine-stimulated striatal DA release may also indicate a compensatory response, and that the primary effect of EB may be on striatal $D_{2}$ DA receptor binding. Further investigation of the mechanisms mediating these responses may clarify the sequence of events that occur following EB administration in OVX rats.

In the present study, CAST rats showed an increase in striatal $\mathrm{D}_{2}$ DA receptor binding $4 \mathrm{~h}$ after EB injection. Previous research has also found that 24-48 $\mathrm{h}$ after repeated or high dose estrogen treatment, there is an increase in striatal $D_{2}$ DA receptor binding in both OVX and intact male rats $[5,6,7,9,12,14,16,18$,
20,22]. In male rats this effect may be mediated by estrogen-induced prolactin release, since after estrogen administration the increase in striatal $\mathrm{D}_{2} \mathrm{DA}$ receptor binding in male rats has been related to circulating serum concentrations of prolactin $[19,21,22]$. In add1tion, hypophysectomized male rats that show no prolactin release after estrogen injection show no change in striatal $\mathrm{D}_{2} \mathrm{DA}$ receptor binding, whereas, similarly hypophysectomized female rats do show a significant estrogen induced increase in striatal $\mathrm{D}_{2}$ DA receptor binding $[7,10]$. Considering these previous findings, the present results showing a delayed $(4 \mathrm{~h})$ increase in striatal $\mathrm{D}_{2}$ DA receptor binding in CAST rats but not OVX rats may represent a sex-specific response to the secondary effects of estrogen, possibly mediated by prolactin. However, without directly correlating changes in receptor binding with circulating prolactin concentrations, this hypothesis remains speculative.

The present study also revealed a sex difference in striatal $\mathrm{D}_{2} \mathrm{DA}$ receptor binding in the lateral region of the rostral striatum, with CAST rats having significantly less binding than OVX rats. Binding studies using membranes from whole homogenized striatum have found that $D_{2}$ DA receptor binding is not significantly different when intact male and female rats are compared [20]. There have been no previous reports comparing striatal $\mathrm{D}_{2}$ DA receptor binding in CAST rats and OVX rats. Since in vivo microdialysis studies of basal extracellular striatal DA have found higher concentrations of DA in CAST rats compared to OVX rats [3], the sex difference in striatal $D_{2}$ DA receptor binding may represent a postsynaptic response to greater striatal DA concentrations in CAST rats relative to OVX rats. Experiments in progress will further investigate this sex difference.

Little is known about the regional differences in striatal function. Although a topographical organization related to cortical regions has been suggested, there is considerable overlap in innervation of the striatum [13]. Data from the current study and previous work [12,33] suggest that $D_{2}$ DA receptor binding in the lateral region of the caudal striatum is more sens1tive to estrogen than other areas of the striatum, but only in female rats. Furthermore, the present study has revealed that this area of the striatum responds rapidly to $\mathrm{EB}$ (within $30 \mathrm{~min}$ ) with a decrease in $\mathrm{D}_{2} \mathrm{DA}$ receptor binding. Previous research from this laboratory has demonstrated that amphetamine-induced stereotyped head and forelimb movements as well as amphetamine-induce general activity are enhanced 30 min after a single injection of estrogen in OVX rats [3]. Following repeated estrogen treatment in OVX rats, apomorphine-induced stereotyped behavior is more intense than the response seen in control animals [15], and the oral component of apomorphine-induced stereotypy seems to be most sensitive to repeated es- 
trogen treatment [24]. Taken together, these findings suggest that the $D_{2}$ DA receptor response in the estrogen-sensitive regions of the striatum is particularly important for stereotyped movements of the mouth, head and forelimbs. Additional studies looking at sex differences and/or hormonal influences on spontaneously generated striatal-mediated behaviors are necessary to take full advantage of this paradigm. This brief discussion illustrates, however, the potential value of studying sex differences or hormone influences on striatal mediated behaviors to help elucidate the regional specificity of striatal function.

Acknowledgements. This research was supported by a grant from the National Science Foundation BNS9021966. T J B. was supported by a training grant to the UM Reproductive Sciences Program (HD07048). We would like to thank Susan Rybak and Carmelıta Reyes for their valuable assistance on this project. We also extend a special thanks to Dr Roger Albin for many valuable discussions and for making available to the authors equipment in his laboratory.

\section{References}

[1] Becker, J.B, Estrogen rapidly potentıates amphetamıne-1nduced striatal dopamine release and rotational behavior durıng microdialysis, Neuroscı Lett, 118 (1990) 169-171

[2] Butcher, R.L., Collıns, W.E and Fugo, N.W., Plasma concentratıon of LH, FSH, prolactın, progesterone and estradıol $-17-\beta$ throughout the 4-day estrous cycle of the rat, Endocrinology, 94 (1974) 1704-1708

[3] Castner, S.A., Xiao, L. and Becker, J.B., Sex differences in striatal dopamıne: in vivo microdialysis and behavioral studies, Brain Res, 610 (1993) 127-134

[4] Clopton, J.K. and Gordon, J.H., In vivo effects of estrogen and 2-hydroxyestradiol on $\mathrm{D}_{2}$ dopamıne receptor agonıst affınity states in rat striatum, J. Neural Transm., 66 (1986) 13-20.

[5] Clopton, J.K. and Gordon, J.H., The possible role of 2-hydroxyestradiol in the development of estrogen-induced striatal dopamıne receptor hypersensitivity, Brain Res., 333 (1985) 1-10.

[6] Di Paolo, T , Bedard, P.J., Dupont, A., Poyet, P and Labrie, F., Effects of estradiol on intact and denervated striatal dopamine receptors and on dopamine levels a biochemical and behavioral study, Can J Physiol Pharmacol, 60 (1982) 350-7.

[7] Di Paolo, T., Daigle, $M$ and Labrie, F., Effect of estradiol and haloperidol on hypophysectomized rat brain dopamine receptors, Psychoneuroendocrinology, 9 (1984) 399-404.

[8] Di Paolo, T., Falardeau, P. and Morissette, M., Striatal $D_{2}$ dopamine agonist binding sites fluctuate during the rat estrous cycle, Llfe Scl , 43 (1988) 665-672

[9] Di Paolo, T., Poyet, P. and Labrie, F., Effect of chronic estradıol and haloperidol treatment on striatal dopamine receptors, Eur J Pharmacol., 73 (1981) 105-6.

[10] D1 Paolo, T., Poyet, P and Labrie, F., Effect of prolactın and estradiol on rat striatal dopamıne receptors, Llfe Sct, 31 (1982) 2921-2929.

[11] Di Paolo, T., Poyet, P and Labrie, F., Prolactın and estradiol increase stratal dopamine receptor density in intact, castrated and hypophysectomized rats, Prog Neuropsychopharmacol Biol Psychiatry, 6 (1982) 377-382
[12] Falardeau, P. and Di Paolo, T., Regional effect of estradiol on rat caudate-putamen dopamine receptors: lateral-medial differences, Neurosct. Lett., 74 (1987) 43-48.

[13] Gerfen, C.R., The neostriatal mosaic: the retterated processing unit. In M. Sandler (Ed), Neurotransmitter Interactions in the Basal Gangla, Raven Press, New York, 1987, pp. 19-29.

[14] Goetz, C, Bourgoın, S., Cesselın, F , Brandı, A., Bression, D, Martınet, $M$, Peillon, $F$ and Hammon, $M$, Alteratıons in central neurotransmitter receptor binding sites following estradiol implantation in female rats, Neurochem Int, 5 (1983) $375-383$

[15] Gordon, J.H, Modulation of apomorphine-induced stereotypy by estrogen time course and dose response, Brain Res Bull, 5 (1980) 679-682.

[16] Gordon, J H and Perry, K.O., Pre- and postsynaptıc neurochemical alterations following estrogen- induced striatal dopamıne hypo- and hypersensitivity, Brain Res. Bull, 10 (1983) $425-428$

[17] Henderson, S.R, Baker, C and Fink, G, Oestradiol-17 $\beta$ and pituitary responsiveness to luteınızing hormone releasing factor in the rat a study using rectangular pulses of estradiol- $17 \beta$ monitored by non-chromatographic radıommunoassay, J. Endocrinol, 73 (1977) 441-453

[18] Hruska, R E, Elevatıon of striatal dopamıne receptors by estrogen: dose and tıme studies, $J$ Neurochem , 47 (1986) 1908-1915

[19] Hruska, R.E., Modulatory role for prolactın in the elevation of striatal dopamıne receptor density induced by chronic treatment with dopamine receptor antagonists, Brain Res Bull, 16 (1986) 331-339

[20] Hruska, R E , Ludmer, L M , Pitman, K T, De Ryck, M. and Silbergeld, E K, Effects of estrogen on striatal dopamıne receptor function in male and female rats. Pharmacol. Biochem Behai', 16 (1982) 285-291

[21] Hruska, R.E., Pitman, K.T., Sılbergeld, E.K. and Ludmer, L.M., Prolactin increases the density of striatal dopamine receptors in normal and hypophysectomized male rats, Llfe Sct, 30 (1982) $547-553$

[22] Hruska, R.E. and Silbergeld, E K, Estrogen treatment enhances dopamine receptor sensitivity in the rat striatum, Eur $J$ Pharmacol , 61 (1980) 397-400

[23] Hruska, R.E. and Silbergeld, E K., Increased dopamıne receptor sensitivity after estrogen treatment using the rat rotation model, Sclence, 208 (1980) 1466-1468

[24] Johnson, $\mathbf{N}$ and Stevens, $\mathbf{R}$, Estrogen treatment increases the oral component of apomorphine-induced stereotypy, Eur $J$ Pharmacol, 100 (1984) 181-188.

[25] Joyce, J.N., Loeschen, S K. and Marshall, J.F., Dopamıne $\mathrm{D}_{2}$ receptors in rat caudate putamen the lateral to medial gradient does not correspond to dopaminergic innervation, Brain Res, 338 (1985) 209-218

[26] Levesque, D. and Di Paolo, T, Modulatıon by estradıol and progesterone of the GTP effect on striatal $\mathrm{D}_{2}$ dopamine receptors, Blochem. Phamacol., 45 (1993) 723-733

[27] Levesque, D. and Di Paolo, T., Rapid conversion of high into low striatal $\mathrm{D}_{2}$-dopamine receptor agonist bindıng states after an acute physiological dose of 17 beta- estradiol, Neuroscl Lett, 88 (1988) 113-118.

[28] Miller, J C., Sex differences in dopaminergic and cholınergic activity and function in the nigrostriatal system of the rat, Psychneuroendocrinology, 8 (1983) 225-236

[29] Morissette, M., Levesque, D and Di Paolo, T, Effect of chronic estradiol treatment on brain dopamine receptor reappearance after irreversible receptor blockade an autoradiographic study, Mol. Pharmacol., 42 (1992) 480-488.

[30] Pan, H, Frey, K., Young, A and Penney, J, Changes in $\left[{ }^{3} \mathrm{H}\right]$ muscimol binding in substantia nigra, entopeduncular nucleus, globus pallıdus, and thalamus after striatal lesions as 
demonstrated by quantitative receptor autoradiography, $J \mathrm{Nelt}$ rose , 3 (1983) 1189-1198

[31] Paxınos, G and Watson, C, The Rat Brain in Stereotaxic Coordlnates, 2nd edn, Academic Press, New York, 1986

[32] Richfield, E K, Penney, J B and Young, A B., Anatomical and affinity state comparisons between dopamine $D_{1}$ and $D_{2}$ receptors in the rat central nervous system. Neuroscience, 30 (1989) 767-777

[33] Roy, E.J., Buyer, D.R and Licarı, V A, Estradiol in the striatum effects on behavior and dopamıne receptors but no evi- dence for membrane sterold receptors. Brain Res Bull, 25 (1990) 221-227

[34] Schumacher, M, Corrmı, H, Frankfurt, M and McEwen, B S. Localized actions of progesterone in hypothalamus involve oxytocin, Proc Natl Acad Sct USA. 86 (1989) 6798

[35] Tonnaer, J A, Leınders, T and van Delft. A M, Ovariectomy and subchronic estradiol-17 $\beta$ admınistration decrease dopamıne $\mathrm{D}_{1}$ and $\mathrm{D}_{2}$ receptors in rat struatum, Psvchoneuroendocrinology. 14 (1989) 469-76 